\title{
Observations on the biology and distribution of Uresiphita reversalis (Lepidoptera, Crambidae), a defoliator of the native tree Calia secundiflora in México
}

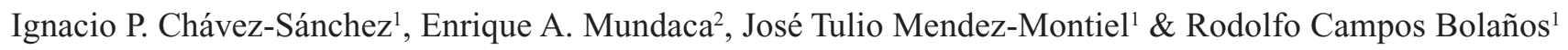

${ }^{1}$ División de Ciencias Forestales, Universidad Autónoma Chapingo Km 38.5. Carretera México-Texcoco. Caja Postal 56230. Chapingo, Estado de
México, México. chavez_ignacio@hotmail.com,jmendezm@taurus.chapingo.mx
${ }^{2}$ Escuela de Agronomía, Facultad de Ciencias Agrarias y Forestales, Casilla 7-D, Universidad Católica del Maule, Curicó, Chile. emundaca@ucm.cl

\begin{abstract}
Observations on the biology and distribution of Uresiphita reversalis (Lepidoptera, Crambidae), a defoliator of the native tree Calia secundiflora in México. Uresiphita reversalis (Guenée, 1854) feeding on Calia secundiflora (Ortega) Yakovlev is recorded for the first time in the state of Hidalgo, Mexico. New aspects regarding the life cycle, feeding behaviour, geographical distribution and host plant damage by U. reversalis on C. secundiflora are here presented and discussed.
\end{abstract}

KEYWORDS. Genista caterpillar; Hidalgo; Insecta; mescal bean.

Uresiphita reversalis (Guenée, 1854), also known as the "genista caterpillar" (Leen 1997), belongs to the small genus Uresiphita, of the subfamily Pyraustinae (Crambidae) (Munroe 1976). Uresiphita reversalis is the only species of the genus known to occur in North America with a latitudinal distribution that includes Nova Scotia (Canada), parts of the United States and some areas of Mexico (Leen 1992). At a worldwide level, species of the genus Uresiphita cover a wide distribution, including such regions as New Zealand (Mulvay 1978), Australia, southern Europe, Hawaii (Conant 1975) and other Pacific Islands, the Middle East and China (Leen 1997).

In terms of its biology, $U$. reversalis has been described as having a multivoltine life cycle, with a number of annual generations (Leen 1995). Multivoltinisim has been recorded particularly in coastal areas of the United States (Carrel 2001), where $U$. reversalis can be found pupating and occasionally in its adult stage even during winter. Records from California and Florida, for instance, indicate that adults can be collected throughout the entire year (Leen 1995).

Calia secundiflora (Ortega) Yakovlev, known as the "mescal bean", belongs to the family Fabaceae and has been widely studied from a phytochemical point of view due to its toxicity and medicinal properties (Garcia-Mateos et al. 2007). The main chemical components described for $C$. secundiflora have been cytisine and others derived from quinolizidine alkaloids (Hatfield et al. 1977). Cases of intoxication have been seldom reported for humans, but cases of intoxication of bovine cattle, goats and horses have been commonly reported (Aguilar \& Zolla 1982). Its distribution in the American continent occurs from southwestern United States (Hattfield et al. 1977) to the mountains of Oaxaca and Puebla, in southern Mexico (Garcia et al. 1994). In this last locality, $C$. secundiflora is relatively abundant and easy to find in canyons and hills of arid and semiarid areas. Within the Mexican territory, C. secundiflora can also be found in Nuevo León, Coahuila, Sonora, Chihuahua, Tamaulipas, San Luis Potosí, Veracruz, Querétaro, Hidalgo and Tehuacán valley in Puebla (Aguilar \& Zolla 1982). In the states of Hidalgo and Puebla, C. secundiflora occurs in association with Juniperus flaccida Schltdl. (weeping juniper, "enebro") and Pinus cembroides Zucc. (Mexican pinyon, "pino piñonero"), and it is normally called "colorín", "patol", "pitol", "coca", "chocolón", "frijolillo" and/or "frijolito" (Martínez 1979).

In California, $U$. reversalis is a heavy defoliator of the introduced species Genista monspessulana (L.) L.A.S. Johnson (French broom) and of the genus Cytisus (Mastro 1993). Other species in Uresiphita, e.g., U. maorialis (Felder \& Rogenhofer, 1875), are also known to be heavy defoliators of quinolizidine bearing plants of the genera Sophora (Conant 1975; Leen 1997) and Lupinus (Molloy et al. 1991), occurring in high densities on their host plants (Mulvay 1978; Mundaca 2011). In southern areas of the United States $U$. reversalis has been reported as a pest of plants of $C$. secundiflora, causing severe defoliation in infected individuals. In such cases, control measures have included the use of Bacillus thuringiensis Berliner, 1915 and insecticides such 
as Sevin ${ }^{\circledR}$ or diazinon (Crosswhite \& Randall 1985). In Mexico, however, the extent of the damage provoked by $U$. reversalis on $C$. secundiflora has not been assessed.

The aim of this short communication is to contribute to the knowledge of the life cycle of $U$. reversalis living on $C$. secundiflora, to assess the damage provoked by the moth on C. secundiflora and to expand our knowledge of its geographical distribution.

Sampling was carried out between December 2008 and September 2009 in two sites where C. secundiflora plants naturally occurred. Both places where located in the state of Hidalgo and were sampled 10 times on a monthly basis. The first sampling site was located at the locality of Cardonal. Plants of Calia secundiflora occurred in a patch by the main road between Comunidad del Vithe and el Cardonalito (20³8'39"N -99 $07^{\prime} 13^{\prime \prime} \mathrm{W} ; 2189$ meters above the sea level). The second sampling site was located $700 \mathrm{~m}$ from the Zotola town of Metztitlán. The site was located within the boundaries of the Biosphere Reserve of "Barranca de Metztitlán” (20³3'15" N - 9850’22" W; 1885 meters above the sea level).

Both sites comprised a vegetation type resulting from secondary regeneration, with wide open vegetation free spaces and evidence of intensive goat grazing. Some of the main plant species occurring with $C$. secundiflora were Stenocereus dumortieri (Scheidw.) Buxb. ("órgano cimarrón"), Agave xylonacantha Salm-Dyck ("maguey") and Prosopis laevigata (Humb. \& Bonpl. ex Willd.) M.C. Johnst ("mesquite"). Twentyfour trees of $C$. secundiflora were randomly selected in both sampling sites. Larvae of $U$. reversalis were sampled by shaking a branch of the plant twenty times. Samples were collected into a modified pyramidal beating sheet made using a heavyduty piece of cloth stretched across two diagonal pieces of wood joined at the centre to a collecting jar (Fig. 1). The trap design was originally developed by the arachnologist Dr. Pierre Paquin and collaborators to collect spiders from trees and shrubs foliage and has remained unpublished so far.

Coincidently with the reports made by Leen (1995), it was possible to observe the occurrence of larvae through the entire winter in both sampling areas. Larvae abundances recorded on the sampling sites were relatively low through the ten months of this study. We recorded the highest abundances in April 2009 in Metztitlán and in May 2009 in Cardonal (Fig. 2).

Eggs collected on C. secundiflora leaves (Fig. 3) were kept in the laboratory to be reared under ambient temperature, humidity and normal day-night photoperiod conditions. The eggs hatched between 5 to 6 days after being collected. Eggs were shiny, yellowish, arranged in a way that resembled fish scales and grouped in clusters of variable numbers on the abaxial surface of the leaf as described by Leen (1995). Upon eclosion, the larval stage of $U$. reversalis lasted approximately one month under the previously described conditions. We also observed the occurrence of five instars as described in the literature (Leen 1995). In laboratory conditions, $1^{\text {rd }}$ instar larvae reached $3^{\text {rd }}$ instar within $16.5( \pm 1.5)$ days, reaching an average length of $15 \mathrm{~mm}$. Larvae then,

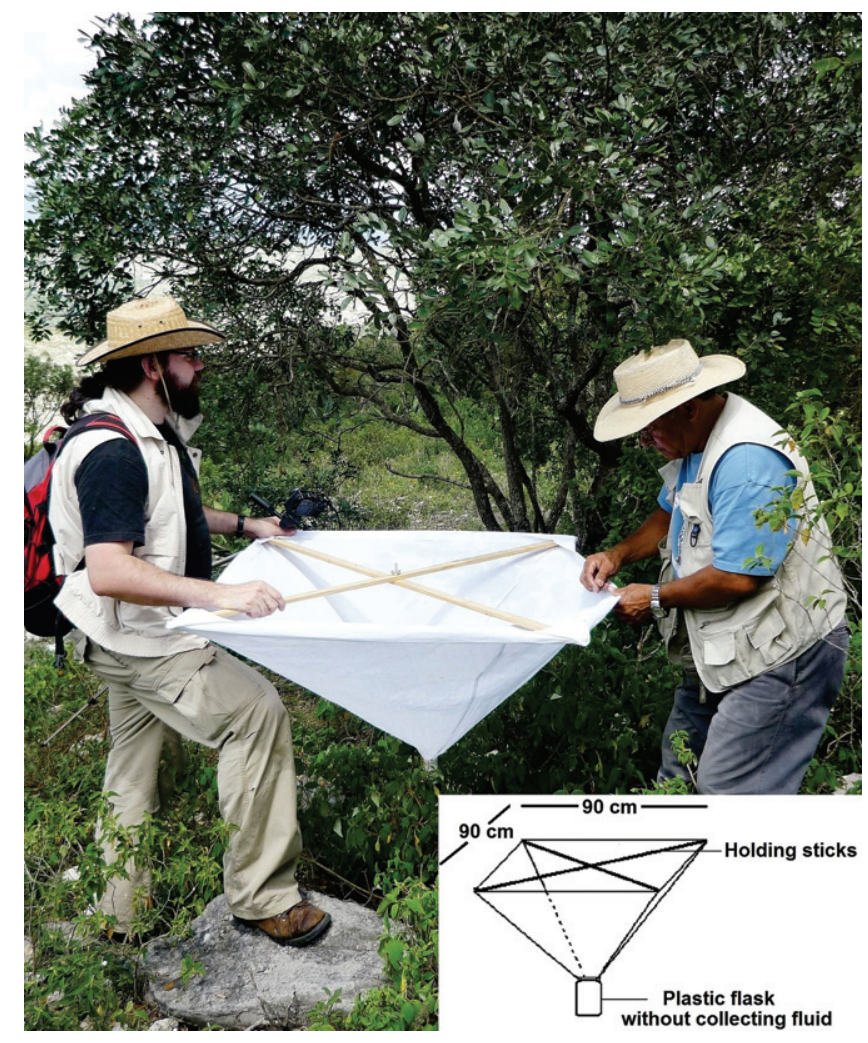

Fig. 1. Pyramidal beating sheet and dimension details. Trap model created and developed by Dr. Pierre Paquin and collaborators (unpublished).

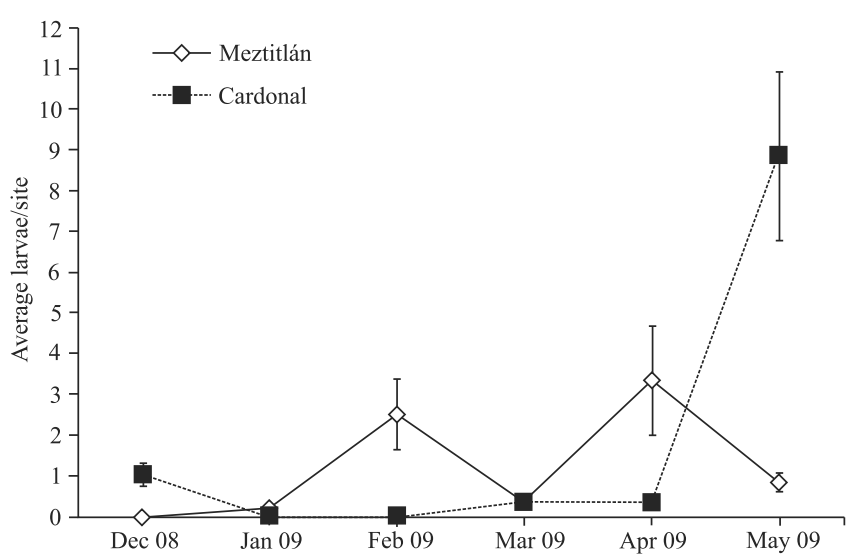

Fig. 2. Accumulated abundances of Uresiphita reversalis larvae recorded in each sampling location, from 24 trees per site, on a monthly basis for 10 months.

reached instars $4^{\text {th }}-5^{\text {th }}$ within the following $11( \pm 1)$ days, reaching an average length of $35 \mathrm{~mm}$ previous to pupation.

We recorded larvae in the field feeding during the day on fresh leaves, buds and young pods of the host plant (Figs. 45). Feeding activity of the larvae is easy to identify in the field, as defoliated branches and nearby leaves and pods appear covered by silk threads produced by the larvae. Pupation occurred away from the main host plant. The larva leaves the main host plant and nets a silk-made cocoon before initiating the pupation (Fig. 6). Pupae completed their develop- 



Figs. 3-8. Life cycle stages of Uresiphita reversalis observed in Hidalgo, Mexico. 3, Egg cluster on the abaxial area of a leaf of Calia secundiflora. 4, Early and 5, last larval instars feeding on $C$. secundiflora pods. 6, Pupa surrounded by a silk made cocoon. 7, Ventral and 8, dorsal view of the adult.

ment into adults within $20( \pm 5)$ days in laboratory conditions. Emerged adults exhibited a whitish to pale grey ventral area (Fig. 7), with dark brown coloured forewings (Fig. $8)$, Adults survived $10( \pm 4)$ days after emerging in our rearing cages. We recorded oviposition within $3.5( \pm 0.5)$ days after the emergence of adult females. The overall development from egg to adult of $U$. reversalis took $56( \pm 7)$ days under laboratory conditions.

So far, consumption of leaves/leaflets has been the main damage described for $U$. reversalis on its host plant. Our observations showed that larvae feed also on parts of the plant other than leaflets, such as pods and buds. Although larvae abundances observed on C. secundiflora were relatively low, they seem to relate to the phenology of the plant and climatic fluctuations, with higher abundances recorded in warmer summer months.
Moreover, previous records described $U$. reversalis to be present only in northern Mexico (Munroe 1976; Allyson 1981). The presence of $U$. reversalis in the state of Hidalgo, however, represents the southernmost record of this species so far. As the presence of $U$. reversalis in Hidalgo is coincident with the distribution of $C$. secundiflora, we consider it necessary to carry out further surveys in states such as Puebla, where the host plant $C$. secundiflora and other potential host plants are known to occur, but the moth has not been recorded yet.

Although larvae of $U$. reversalis were observed on trees of C. secundiflora, the extent of the defoliation was, in general, low. Our observations indicate that in the studied areas, the presence of $U$. reversalis on $C$. secundiflora does not always result in heavy defoliation of the host plant as previously reported by Crosswhite \& Randall (1985) in the United States. 


\section{ACKNOWLEDGEMENTS}

We would like to thank the Universidad Autónoma Chapingo, División de Ciencias Forestales, Victoria University of Wellington and the New Zealand government through the Study Abroad Scholarship scheme. Thanks also to Enrique Guizar Nolazco and Dr. Diodoro Granados Sánchez for their observations made to the research project. Finally, thanks to the Biosphere Reserve "Barranca de Metztitlán" and especially to Maru and Max for their extraordinary support in carrying out the field work. To Dr. Pierre Paquin for kindly sharing his trap design with us and to Dr. Mariana LazzaroSalazar for proof reading this manuscript.

\section{REFERENCES}

Aguilar, C.A. \& Zolla, C. 1982. Plantas tóxicas de México. México, D.F., Instituto Mexicano del Seguro Social, i+271 p.

Allyson, S. 1981. Last instar larvae of Pyraustini of America north of Mexico (Lepidoptera: Pyralidae). The Canadian Entomologist 113: 463-518.

Carrel, J.E. 2001. Response of predaceous arthropods to chemically defended larvae of the pyralid moth Uresiphita reversalis (Guenée) (Lepidoptera: Pyralidae). Journal of the Kansas Entomological Society 74: 128-135.

Conant, M. 1975. Seasonal abundance of the Mamane moth, its nuclear polyhedrosis virus and its parasites. Honolulu, Island Ecosystems, Integrated Research Program, Ecosystem Analysis Studies, International Biological Program (IBP) Report \#64, 38 p.

Crosswhite, C.D. \& Randall, C. 1985. Damage to mescal bean (Sophora secundiflora) by a pyralid moth (Uresiphita reversalis). Desert Plants 7: 32 .

García, M.A., Tenorio, L.P. \& Reyes, S.J. 1994. El endemismo en la flora fanerogámica de la Mixteca Alta, Oaxaca-Puebla, México. Acta Botánica Mexicana 27: 53-73.

García-Mateos, R., Soto-Hernández, M., Zavala-Chávez, F. \& Kite, G. 2007. Quinolizidine alkaloides in Calia secundiflora (Fabaceae). Agrociencia 41: 161-167.

Hatfield, G.M., Valdes, L.J.J., Keller, W.J., Merril, W.L. \& Jones, V.H. 1977. An investigation of Sophora secundiflora seeds (mescal beans). Lloydia 40: 374-383.

Leen, R. 1992. Not so novel interactions of Uresiphita ssp. (Crambidae) and their host plants. Ph.D. dissertation. Berkeley, University of California, $124 \mathrm{p}$.

Leen, R. 1995. Biology of Uresiphita reversalis (Guenée) and comparison with $U$. polygonalis maorialis (Felder) (Crambidae). Journal of Lepidopterists' Society 49: 163-170.

Leen, R. 1997. Larval Hosts of Uresiphita Huebner (Crambidae). Journal of the Lepidopterists' Society 51: 139-148.

Martínez, M. 1979. Catálogo de nombres vulgares y científicos de plantas mexicanas. México D.F., Fondo de Cultura Económica. i+1220 p.

Mastro, L.A. 1993. A study on the natural history of Cytisus on Santa Catalina Island with an emphasis on biological control, p.105-114. In: Hochberg, F.G. (org.). Third California Islands Symposium: Recent advances in research on the Californian Islands. Santa Barbara, Santa Barbara Museum of Natural History, i+661 p.

Molloy, B.P.J., Partridge, T R. \& Thomas, W.P. 1991. Decline of tree lupin (Lupinus arboreus) on Kaitorete Spit, Canterbury, New Zealand, 19841990. New Zealand Journal of Botany 29: 349-352.

Mundaca, E.A. 2011. Observations on emergence rates of Meteorus pulchricornis (Hymenoptera: Braconidae) and densities of Uresiphita polygonalis maorialis (Lepidoptera: Crambidae) larvae. New Zealand Journal of Zoology 38: 337-341.

Mulvay, R.T. 1978. Biology of the kowhai moth, Uresiphita polygonalis maorialis. M. Sc. Thesis. University of Auckland, 30 p.

Munroe, E. 1976. Pyraloidea Pyralidae (Part). In the moths of America North of Mexico including Greenland. London, Wedge Entomological Research Foundation, Fascicle 13.2, 78p 